REQUIRED COMPETENCIES

IN PUBLIC ADMINISTRATION

STUDY PROGRAMS

\author{
Janez STARE \\ Maja KLUN
}

Janez STARE (corresponding author)

Associate professor, Faculty of Administration,

University of Ljubljana, Ljubljana, Slovenia

Tel.: 00386-1-5805.585

E-mail: janez.stare@fu.uni-lj.si

\section{Maja KLUN}

Professor, Faculty of Administration,

University of Ljubljana, Ljubljana, Slovenia

Tel.: 00386-1-5805.547

E-mail: maja.klun@fu.uni-lj.si
Abstract

In the evaluation of undergraduate and graduate study programs, there is an important issue about which competencies must be acquired by graduates. This study tested the importance of competencies in public administration study programs in the light of expectations of employers in Slovenian public administration. The aim of the research was to find out how various competencies acquired in higher education (undergraduate and graduate study in public administration) are evaluated by employers in public administration. On the basis of analysis of findings of similar research projects, the competencies contained in programs by renowned universities and competencies defined for the work positions, a set of discipline-specific competencies (61) were designed. Research was conducted in 2015 and involved 343 respondents. A qualitative research method (survey) was used to collect the data which were then analyzed with the SPSS statistical program and Microsoft Excel. The results show that the competencies related to ethics and ethical behavior were evaluated as the most important; generic competencies are better assessed than specific ones and on average the competencies received a higher assessment for graduates (compare to undergraduates) positions.

Keywords: competencies, public administration, employers, study programs, higher education. 


\section{Introduction}

The concept of quality in higher education has been drawing attention of all interested parties in the education sector over the last few decades (Tasopoulou and Tsiotras, 2017). Both universities and employers, with the renewal of higher education programs (as a consequence of the Bologna process), gave special emphasis to competencies. A competence based approach could be considered as an attempt to make higher education institutions more standardized, comparable, accountable and cost-effective (Želvys and Akzholov, 2016). This raises the question of what competencies are, and which, from the perspective of employers, provide the expected 'standardized' qualifications. There are two views of 'examining' competencies: examining competencies in actual work practice and examining competencies in educational programs. Despite the different definitions of the concept of competencies in work and competencies in educational programs, the idea is that the study programs should primarily develop those competencies that the working environment recognizes as important. Despite the large variety of definitions of the concept of competency, all competency involves knowledge, procedure and attitudes combined towards one goal, head knowledge (understanding), know-how (skills, abilities, aptitudes and capabilities), knowing how to be (attitudes), knowing what to be like (beliefs and values), and being able to do (means and resources) (Martínez, Moreno and Brage, 2014).

Higher education programs in the field of public administration must provide not only discipline-specific fundamental knowledge but also the general competencies required by the labor market. In the context of our research, two research questions were examined:

- Which competencies do employers expect from public administration graduates?

- Are different competencies expected for positions requiring a different level of education (undergraduate or graduate degree)?

In our research, we wanted to contribute to the literature on several points. The aim of the research was to evaluate the required competencies for a specific academic field (public administration) from the employers' perception. At the same time, the difference between the required competencies according to the study degree and workplace was examined and, further, the importance of specific competencies against general ones were evaluated. In the field of public administration, in literature, there are a few studies on competencies determined by employers. For example Martínez, Moreno and Brage (2014) presented how the civil servants evaluated some general competencies required for Spanish public administration. Some other research discusses or evaluates selected competencies. Van Jaarsveldt and Wessels (2015) evaluated the importance and provision of ICT competencies in the public administration curricula in South Africa, and Awortwi (2010) presented the importance of selected competencies for the success of public administration reforms. A general overview of the different standards and connected competencies in public administration education is presented in the book edited by Rosenbaum (2015). 
The following section starts with a literature review on the determination of competencies in higher education. The next section defines the competencies collected from the different sources and continues by presenting the research methodology and results. In conclusion, the importance of the findings of the study is presented.

\section{The acquisition of competencies in higher education}

Several authors suggest that there has been limited academic research into the relationship between higher education institutions and organizations with regard to competencies that are linked to placements or a study degree or academic discipline (Frasquet, Calderón and Cervera, 2012; Plewa and Quester, 2007). Nevertheless there are also several studies that include the opinions of professionals or employers on the required competencies in different disciplines (Frasquet, Calderón and Cervera, 2012; Boni and Lozano, 2007; Clemente-Ricolfe and Escribá-Pérez, 2013; Borza and Crișan, 2012; Oduma and Ile, 2012; Profiroiu, 2013; Martínez, Moreno and Brage, 2014; Varga, Hajós and Szira, 2016). In most cases, studies highlighted the increasing importance of general knowledge and competencies and the general competencies seem to be even more important than specific ones (Brown and Smetherham, 2006; Azevedo et al., 2012; European Commission, 2010). On the other hand, Jurše and Tominc (2008) and, for some specializations, the European Commission (2010) found that professional competencies are slightly more elevated than general competencies.

According to different research (Kuijpers and Meijers, 2012; Kuijpers and Scheerens, 2006; Savickas, 2000; Giddens, 1991), the individual is expected to demonstrate increasing self-directedness, both on the labor market and in society as a whole. As a result of the trend, different authors pointed out the importance of changing teaching methods (Kuijpers, Schyns and Scheerens, 2006; Winterton, 2009; Vila, Perez and Morillas, 2012; Avargil et al., 2012; Gómez, Aranda and Santos, 2017) to more proactive and problem-based learning.

In the workplace, we use our competencies to perform a variety of behaviors and activities, which in turn generate outputs (products and services) that we provide to others. It is the quality of these outputs and the reactions of those who receive them that lead to results with positive, negative or neutral consequences for the organizations: the people who work there and its suppliers, shareholders, clients and customers (Picket, 1998, p. 103). The identification and assessment of competencies, as well as the development of competency-based management frameworks to support activities such as 'gap analysis', recruitment, learning and other key human resource processes, all reflect an acknowledgement by organizations that their workforce is key to their success in the modern workplace (Bonder, Bouchard and Bellemare, 2011, p. 2).

\section{Determination of the set of competencies}

The tendency for the most qualified workforce in the public administration requires competent graduates. The definitions of which competencies are involved are numerous and varied. Many universities ensure the adequacy of competencies in 
their study programs and try to meet higher standards which are defined differently, either as requirements for the acquisition of sectorial accreditations or in the form of recommendations of the authority in the field. For this reason, we decided to use a long list of general competencies that usually, in other research, give a more comprehensive evaluation and better contribute to public administration studies. In order to determine the set of competencies, the competencies from different sources were used:

- competencies highlighted as important by the projects to date and peer associations (TUNING: project which has developed into a process, an approach to (re)designing, developing, implementing, evaluating and enhancing quality of first, second and third cycle degree programs, EAPAA: The European Association for Public Administration Accreditation, NASPAA: Network of Schools of Public Policy, Affairs and Administration, IASIA: The International Association of Schools and Institutes of Administration);

- competencies identified as the most important in theoretical contributions in the studied field and highlighted as important by renowned universities in their study programs (EAPAA, NASPAA, IASIA accredited programs and other higher education programs in the field of administrative sciences); and

- competencies highlighted in actual work practice to define the work (systematization).

The results of the Tuning project represent one of the starting points of our research, serving in particular as a starting point for compiling a set of competencies. Connecting over 100 European universities, the project is aimed at developing concrete suggestions for implementing the Bologna process at the level of higher education institutions and individual subject fields. Tuning (2016) has designed a methodology for the (re)shaping, development, introduction and evaluation of study programs for each of the three Bologna cycles. When it comes to the subject fields, one of the five sets selected was the field of generic and subject-specific competencies. Tuning distinguishes between three forms of generic competencies:

- instrumental or applicable competencies: cognitive, methodological, technological and linguistic abilities;

- interpersonal competencies: the abilities of an individual, such as the ability to behave in society and to cooperate; and

- systemic competencies: skills and abilities that concern entire systems (a combination of understanding, susceptibility, knowledge and the necessary previously obtained knowledge and interpersonal competencies).

In order to determine the most important generic competencies for each academic field, an extensive consultation with graduates, employers and academic staff was organized in the first stage of the Tuning project. The set of the most suitable generic competencies differed somewhat from subject field to subject field, but the majority of the competencies were relatively similar. Typical academic competencies such as 
the skills of analysis, synthesis, learning and problem-solving were identified as the most important in all fields. Other generic competencies such as the skill of applying knowledge in practice, the skill of adapting to new situations, the concern for quality, the ability to manage information, the skill of independent work, the skill of teamwork, the skill of organization, spoken and written communication in the mother tongue and interpersonal skills were described mainly by graduates and employers as highly important for employability. Graduates and employers also found that some of the above competencies are more useful and better developed than others. They highlighted the fact that more attention should be devoted to a specific number of generic competencies to ensure that students are better prepared for their future positions. The results of this extensive discussion were presented in the project report after the first stage (Gonzales and Wagenaar, 2003; Gonzales and Wagenaar, 2005).

'The aim of the Tuning project was to contribute to the main objectives of the Bologna process by the transformation of traditional degrees into bachelor and master degrees and the reconstruction of the logic of their underlying study programs. Tuning aimed to implement the Bologna process at a university level and concentrated on transparency and the development of a common language in the description of HE programs, not least to enhance comparability and to foster their international recognition' (Lokhoff et al., 2010, p. 11).

However, still more important for our research is the Tuning-PA project, which is inspired by the Tuning Project. Tuning-PA, which was carried out under the European Association for Public Administration Accreditation (EAPAA) aimed to arrive at a set of competencies that are relevant for Public Administration degree programs in Europe, and that can be used by programs to articulate their specific aims and objectives. In this project, a set of 31 generic competencies (Tuning Generic Competencies) where developed and tested (in the sense of their relevance for academic jobs for graduates and realization in certain degree programs) in more than 10 disciplines and in more than 15 countries through questionnaires for employers, graduates and academics (Reichard and van der Krogt, 2014).

In the area of improving the quality of public administration education, there is, in addition to the EAPAA 'covering' the European space, another important institution in the Network of Schools of Public Policy, Affairs and Administration (NASPAA). In the accreditation procedure for education in public administration, the NASPAA covers various competence aspects. The majority of the information regarding the competencies required under the NASPAA standard can be gleaned from the provisions of Standard 5 (Standard 5 Matching Operations with the Mission: Student Learning). The required knowledge includes five areas of abilities (NASPAA, 2014):

- for management and governance in the public sector;

- for cooperation and active contribution to policy-making;

- for analysis, synthesis, critical thinking, problem-solving and decision-making;

- for articulating and applying public service visions; and

- for communicating and interacting with different profiles of associates and citizens. 
In addition to the generic competencies, the NASPAA also requires the formation of specific competencies that reflect the environment or orientation of the educational institution. This may include knowledge of local government, non-profit administration, budget, fiscal policy and analysis, etc. Similar to the IASIA, ICAPA accreditation (ICAPA is the International Commission on the Accreditation of Public Administration Education and Training Programs) expects several generic competencies from studies in public administration, such as professional competence regarding values, ethical behavior, knowledge, respect for life, transparency, accountability, recognition of global interdependence, analytical and critical thinking, dealing with complexity and uncertainty, etc. (ICAPA Accreditation, 2008).

The second part of the study of competencies includes the competencies of study programs. The set of study programs taken into account when collecting competencies was assembled on the basis of publicly available information from the faculty web pages. Study programs were selected from the list of EAPAA, NASPAA and IASIA accredited programs. At the same time, an overview of some other programs (totaling 12) through general internet searches using keywords such as 'Administrative Science', 'Public Administration', 'Public Management' and 'Public Policy' was performed. The focus was mainly on European higher education institutions but also included some US and Canadian universities in the set for comparison. The main focus was on study programs whose contents place them at the very top of public policy and public governance research and development ${ }^{1}$. In total the competencies of 49 first and graduate programs were examined. Study programs place considerable emphasis on developing competencies for the development and independence of students in analyzing, problem-solving and finding practical solutions. The study programs at most higher education institutions give graduates expert competencies and a broad understanding of public administration; graduates are able to define public sector issues, perform quantitative and qualitative data analyses, develop and provide creative solutions and introduce implementation and ethical measures. Some competencies appear in all international study programs (e.g. the ability to analyze, an understanding of PA operation, research work, written and spoken communication, etc.).

Study program competencies at the individual cycle/level of education are entirely comparable and there are no major deviations. However, considerable differences exist in the vertical cycle of education. For example, undergraduate study programs (1st cycle study programs according to the Bologna process) give students general PA knowledge with a certain level of detail. Competencies common in undergraduate

1 UK (Southern New Hampshire University, University of Plymouth, London School of Economics and Political Science), Canada (University of Victoria), USA (Northwestern University, Chicago, Rutgers University NY, Northen Arizona University), Finland (University of Lapland), Germany (Hertie School of Governance, The German University of Administrative Sciences Speyer), The Netherlands (Maastricht University), France (L'ENA). 
study programs include a knowledge of legal, environmental and ethical issues in individual fields, an understanding of PA tradition and the main related theories, the ability to analyze public opinion and form public policies, the ability of negotiation, research, discussion, rhetoric, listening, conflict situation management, etc. In addition to in-depth theoretical knowledge, graduate programs (2nd cycle study programs according to the Bologna process) also provide other competencies, particularly problem-solving, complex analysis, the use of research methods, etc.

An important aspect in determining the desired (necessary, required) competencies are the competencies arising from the concrete nature of work. This is the third part of the study of competencies. In the studied case, this primarily means competencies arising from the descriptions of typical official positions in Slovenian public administration and selected typical Slovenian Local Communities (according to the number of employees). Based on this, two analyses were prepared: an analysis of the document entitled 'Descriptions of Typical Official Positions' and an analysis of typical official positions based on the Systemization of selected Individual Local Communities. In both analyses of typical official positions, we included only the positions open to graduates of PA study programs: official titles in public administration, local community administrations and other state authorities, positions in public agencies, public funds, other public institutes, public economic institutes and other budget users and related positions. The results of both analyses were combined into a common document that solely included positions where a first or graduate degree is required. In the first stage of the analysis, a list of the tasks (including knowledge and skills) required for each official position was prepared. Having analyzed the typical tasks (e.g., managing and coordinating the work of the state authority employees, preparing general acts and other expert and organizational material and instructions from the state authority, etc.), in the second stage, a list was compiled with the competencies necessary for performing these tasks. The analysis of the tasks and the set of necessary competencies show that the typical competencies are related to the following:

- the ability to organize mutual cooperation, coordinate internal organizational units and cooperate with other authorities;

- the ability to participate in developing systemic solutions and other material of the highest complexity;

- the ability to independently prepare demanding analyses, development projects, information, reports and other complex material;

- the ability to manage and make decisions in demanding administrative procedures;

- the ability to manage the most demanding administrative procedures;

- the ability to communicate;

- the ability to lead people and teams; and

- the ability to ensure the development of the organization. 
The study of all the mentioned sources of competencies (study programs, accredited programs, peer associations, systematizations) was a base for determining the list of competencies analyzed in our research.

\section{Methodology}

Based on the list of competencies from the above-mentioned sources, a set of competencies that we wanted to verify with potential employers was created. The set comprised over 1,600 competencies (including skills, desirable behaviors and knowledge), of which about 290 were acquired from theoretical contributions (TUNING (Tuning, 2016; Evenson, 2012; European Commission, 2002)), EAPAA (van der Krogt and Reichard, 2013; Reichard and van der Krogt, 2014; NASPAA (NASPAA, 2009), IASIA (United Nations Department of Economic and Social Affairs, 2008), approximately 940 from different study programs and approximately 380 of them were highlighted in actual work practice (Uredba, 2003).

When compiling the common set of competencies, all the related competencies were combined into a single competency. If for instance, a description of a position of employment required the ability to conduct police control, tax control, etc., the competence was determined as 'the ability to conduct control'. Thus, competencies from different sets were combined into logical units. The competencies that appeared in only a single set were preserved and not combined into units. The combining was mainly possible with generic and general competencies. The subject-specific competencies were related to specific abilities and mostly to specific positions requiring specific knowledge. In order to avoid an excessive set of specific competencies, thus reducing the possibility of accurately completed surveys, specific competencies were included in the survey by giving the respondents the option to evaluate the importance of knowledge in the areas taught in the public administration programs. These areas include economics, management, HR management, law, public policies and finally information systems and web portals. Using this method, a set of 55 generic or general competencies were compliant and, additionally, six areas were determined.

Based on the set of competencies, the survey questionnaire was prepared. The questionnaire included closed-ended questions, while the final two questions were open-ended (the number of employees in the institution and the respondents' general opinion on competencies). The first two questions related to the determination of the type of position (study degree/cycle of education and type of job). The respondents chose from a set of education and employment options. This was followed by an evaluation of the competencies from 1 (I disagree completely) to 5 (I agree completely). The respondents were asked to assess the skills and abilities that an individual, performing the same work as the participant, should have in order to be described as an ideal employee. This was followed by demographic questions on the age, gender and the institution of employment.

To conduct the survey, Google Survey was used. The link to the survey was sent to all the addresses of institutions in the public sector (to the main office or to the HR 
office, with a request to distribute it among the employees who are either experts in the field or HR experts). The survey was conducted from December 2014 to May 2015. There were 343 responses received.

\section{Research results}

The average assessments of the importance of individual competencies according to the position of an employee are analyzed in three ways: together for 1 and 2 cycle degrees, and separately for undergraduate and graduate degrees. The average assessment of each competence based on all the participant responses showed (Table 1) that the competencies related to ethics and ethical behavior were assessed the highest. The competency of communicating in the mother tongue was also assessed very high. The lowest average assessment was given to competencies related to specific areas or knowledge, communication in a foreign language and working in an international environment. The highest rated competence was 'Is respectful to his/her associates' (4.75), the lowest one 'Needs knowledge in the field of public policy-making' (3.42). The difference between the highest and the lowest rated competence is 1.33. Table 1 shows the highest (with an average grade of the maximum to $-10 \%$ difference) and the lowest ranked (with an average grade of the minimum to $+10 \%$ difference) average assessments of competencies.

Table 1: The highest and lowest ranked average assessments of competencies

\begin{tabular}{|c|c|c|c|}
\hline Rank & Competence & Mean & $\begin{array}{c}\text { Std. } \\
\text { Deviation }\end{array}$ \\
\hline I. & Is respectful to his/her associates & 4.75 & .559 \\
\hline II. & Does not take advantage of his/her position for personal gain & 4.73 & .598 \\
\hline III. & Is able to act ethically and make ethical decisions & 4.72 & .591 \\
\hline IV.-V. & Is able to provide detailed feedback to supervisors, other employees and clients & 4.71 & .570 \\
\hline IV.-V. & Is capable of written and spoken communication in the mother tongue & 4.71 & .600 \\
\hline VI.-VII. & Is able to work in accordance with the authorizations given & 4.69 & .564 \\
\hline VI.-VII. & Is trustworthy & 4.69 & .602 \\
\hline VIII. & Makes decisions responsibly & 4.66 & .634 \\
\hline IX. & Works within the legal and agreed deadlines & 4.64 & .615 \\
\hline X.-XI. & Is able to identify his/her mistakes and eliminate them & 4.62 & .629 \\
\hline X.-XI. & Acts under high personal and moral standards & 4.62 & .624 \\
\hline : & : & : & : \\
\hline LX. & Is capable of written and spoken communication in a foreign language & 3.55 & .977 \\
\hline LXI. & Needs knowledge in the field of public policy-making & 3.42 & 1.017 \\
\hline
\end{tabular}

Source: Survey among employers

Next, we wanted to see how the competence assessments differed based on the cycle of education. Since public administration programs educate students for positions that require an undergraduate or graduate degree in Public Administration, respondents with a secondary school education were excluded. This means that 15 responses were excluded from the survey. 114 respondents have (had) an undergraduate de- 
gree, while 213 respondents have (had) a graduate degree or higher. The distinction between degrees is important in terms of research since employment at a particular workplace (thus also performing different levels of work tasks) depends on the cycle of completed education.

The highest evaluated competencies for each cycle of study are shown separately for each group in the figure below (Figure 1). The results show that the highest evaluated competencies for both cycles of study are similar, though there are differences in the average assessment of competencies.

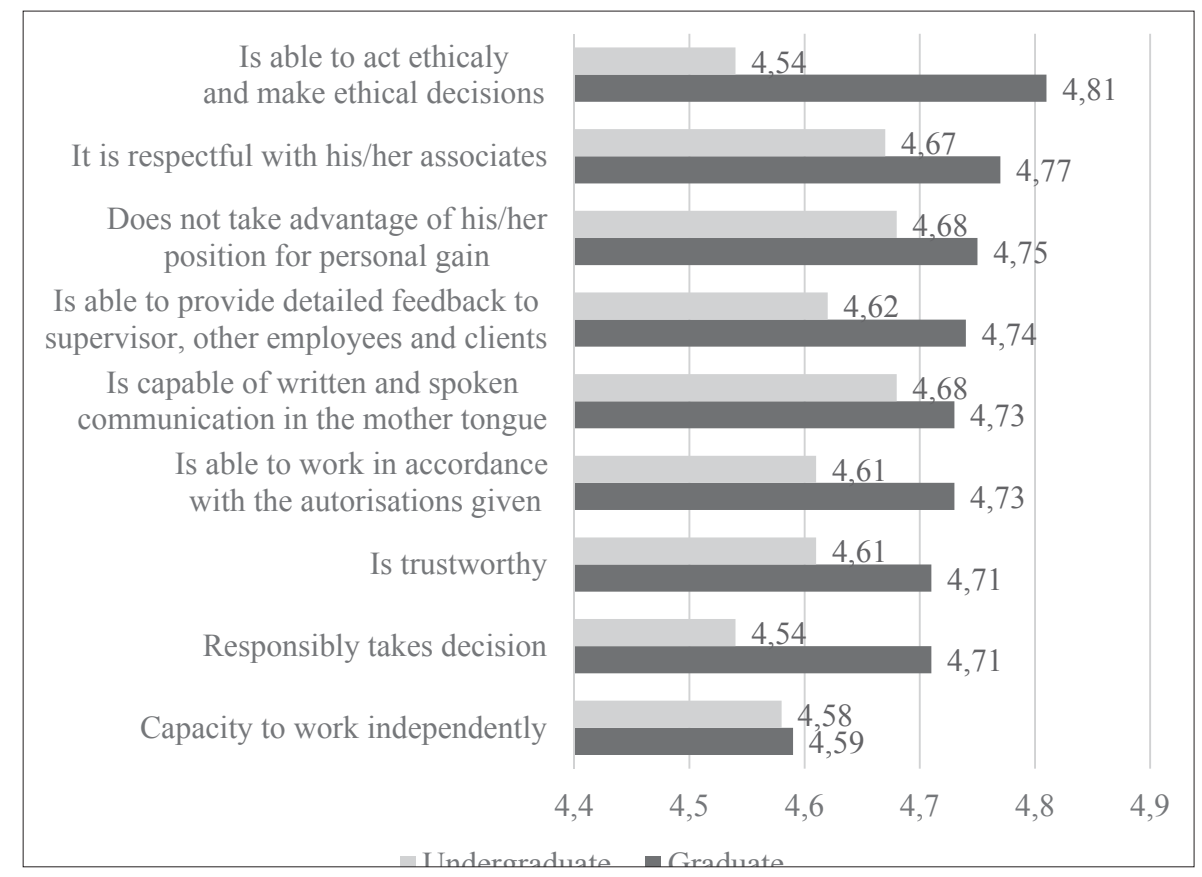

Figure 1: The highest average competency assessments based on the different cycles of education (the 7 highest for each level of education)

Source: Survey among employers

The distribution of competencies according to rank is quite similar. This applies both to those best rated and to the overall range of competencies. Among the bestranked competencies, according to rank (Figure 2), the greatest difference in competency rank is 'Is able to act ethically and make ethical decisions' (rank 1 among competencies of graduate study programs and rank 10 among competencies of undergraduate study programs) and 'The capacity to work independently' (rank 7 among competencies of undergraduate study programs and rank 14 among competencies of graduate study programs). 


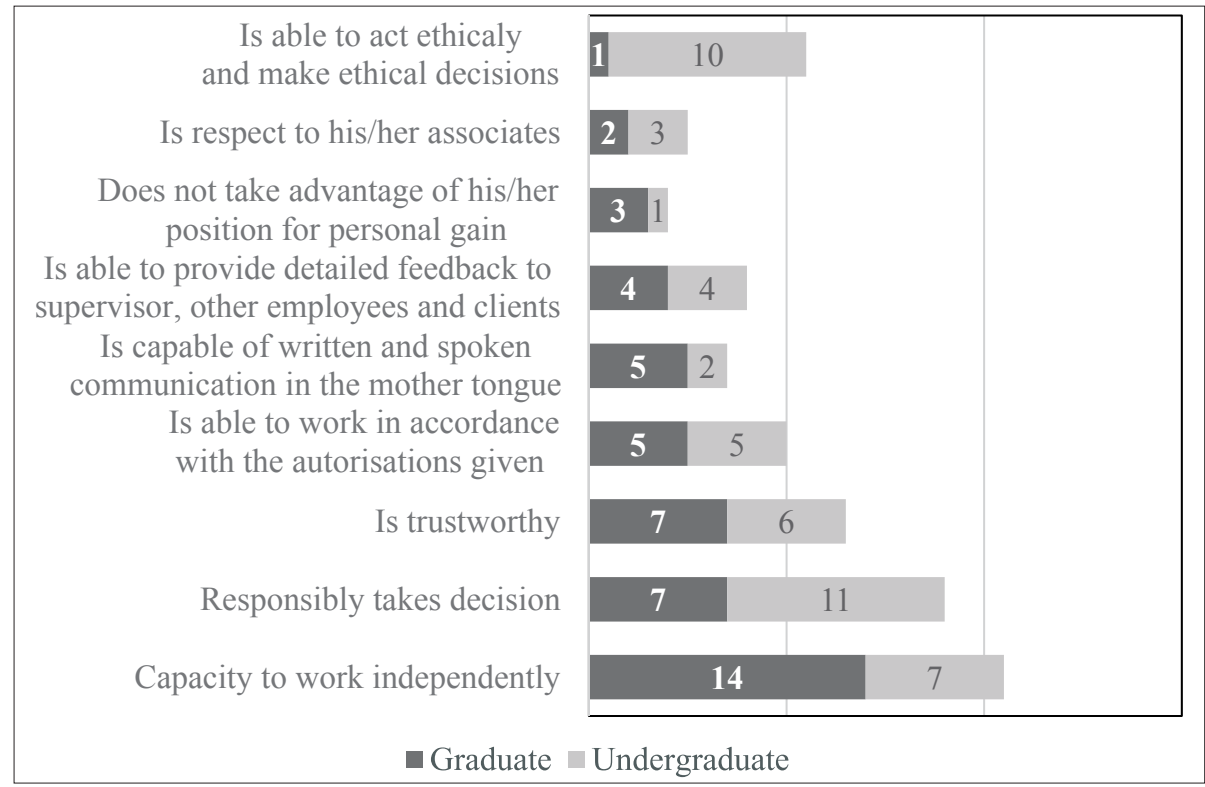

Figure 2: The highest rank of average competency assessments based on the cycle of education

Source: Survey among employers

An analysis of the incidence of Tuning-PA competencies (31 competencies) in terms of the rank of researched competencies (from 1 to 61) was also performed. Tuning-PA competencies have been chosen because they are the most widespread competencies in higher education programs in the European area. The competencies studied in the research were divided into four groups according to the range. In the first group of competencies (rank 1-15), there are only 5 Tuning-PA competencies present; in the second group (rank 16-30) there are 9; in the third (rank 31-45) there are 10; and in the fourth (rank 46-61) 7 Tuning-PA competencies are present. Among the 15 most important competencies, only the following 5 Tuning-PA competencies are listed: ability to act on the basis of ethical reasoning, ability to communicate both orally and through the written word in the first language, make reasoned decisions, determination and perseverance in the given tasks and responsibilities taken and the ability to work autonomously. Thus, among the 15 most important competencies in the area of public administration education, respondents rank only 5 tuning competencies and 10 competencies formed on the basis of other sources already mentioned.

For the competencies assessed by both groups of respondents (undergraduate and graduate degree) a Mann-Whitney test was conducted to confirm or deny the hypothesis that the answers differ between the two groups. The test showed that there were only five competencies where the answers differed. These competencies were assessed higher by the respondents with a higher level of education $(p \leq 0.000)$. These competencies are presented in the next table (Table 2). They are connected to the more demanding positions of employment since they include strategic thinking, anal- 
ysis, evaluation and the assessment of associates. In addition, it is evident from the responses that people with a higher education who also hold higher positions give a higher assessment of the importance of ethical behavior, although this is a competence already highly assessed by all respondents.

Table 2: Mann-Whitney U test results

\begin{tabular}{lcccc}
\hline \multicolumn{1}{c}{ Competencies } & Mann-Whitney U & Wilcoxon W & Z & $\begin{array}{c}\text { Asymp. Sig. } \\
\text { (2-tailed) }\end{array}$ \\
\hline Is able to act ethically and make ethical decisions & 9084.000 & 15412.000 & -4.615 & .000 \\
Thinks strategically & 9146.500 & 15474.500 & -3.630 & .000 \\
Abstract and analytical thinking and synthesizing ideas & 9235.500 & 15563.500 & -3.522 & .000 \\
Is able to evaluate & 9192.000 & 15520.000 & -3.613 & .000 \\
$\begin{array}{l}\text { Evaluates the work results of his/her associates based } \\
\text { on criteria agreed upon in advance }\end{array}$ & 9166.000 & 15494.000 & -3.535 & .000 \\
\hline
\end{tabular}

Source: Survey among employers

The assessment of specific competencies was not statistically different between both groups; nevertheless, the knowledge in the field of economics, management, human resource management and policy-making were evaluated higher for higher positions in public administration, while specific competencies in the field of public sector regulation and e-government were evaluated lower.

The other correlation tests, such as the influence of gender, age, the size of the institution and the type of institution did not show statistically proven correlations. This is in accordance with the second research question that the position of the employee is the determining factor for the required competency.

\section{Discussion}

The study results demonstrate the suitability (importance) of the listed competencies in the PA education programs since they were all assessed very highly. It is interesting that virtually all the competencies received a higher average assessment (the competence is expected to be better developed) in graduates with the exception of three (knows the organization and operation of public administration, needs knowledge in the field of legal acts (e.g. General Administrative Procedure Act, rules, etc.), and needs knowledge in the field of web portal use (e-administration, etc.). Comparison of the presented research with some other research showed several similarities. Martínez, Moreno and Brage (2014) found that the most relevant competencies are self-confidence and self-assurance, communication, and teamwork, which is in accordance with the presented research, where communication and teamwork were also highly evaluated. Clark and Pal (2011, p. 961) highlights value-based behavior and the role that ethical and moral frameworks play in public administration and public policy. But they warn that 'most of the competences we teach are aimed at improving knowledge-based action and involve the acquisition of concepts, techniques, and facts'. Nevertheless, ethical behavior prevails in our research. This can be partly 
linked to recent political 'scandals' in Slovenia and in the EU, which could influence the opinion of the surveyed civil servants.

The results of the research are somewhat surprising in the case of the lowest assessed competencies. These are related to the ability to work in the international environment, knowledge in the field of public policy making and business economics, the ability to engage in entrepreneurial activity, leadership, management and control in public administration. In some other studies these competencies or competencies that are more directly related to leadership, management and/or public governance are more exposed (Forgues-Savage and Wong, 2017; Shevchenko, 2016; Melnikova, 2013; Clark and Pal, 2011).

According to the highest assessed competencies, the main difference in the perception of competency seems to be in the relationship between generic and specific competencies. Generic competencies seem to be more important to respondents. Such evaluation is expected since mentioned competencies are more important in terms of changing the working environment and jobs. It was similarl also to other research (ie., Manly, McKnight and Thomas, 2008; Lowden et al., 2011; NCVER, 2003). A logical explanation for the low assessed competencies related to foreign language activities is that the majority of respondents come from organizations that mostly do business with 'domestic' customers and rarely with customers abroad. In addition to other studies (Civil Services Human Resources, 2015; American Public Health Association, 2001; Lee, 2008), the presented results showed that some specific knowledge is more important for undergraduate studies (competencies needed for practice, PA operation and legal acts) compared to graduate studies (economics, HR management, policy-making). At the same time, there are some competencies that are statistically different and more important for higher positions (analytical and strategic thinking, ethical decision making, and evaluation capabilities).

Tuning-PA (Reichard, and van der Krogt, 2014) also highlights the importance of generic competencies. However, it is true that Tuning-PA competencies have been assessed worse than most other generic competencies analyzed in this project. The findings can also be reasonably linked to the Workforce Planning Resource Guide of Public Sector Human Resource Professionals (IPMA-HR, 2005), which defines competencies as 'sets of behaviors (encompassing skills, knowledge, abilities and personal attributes) that, taken together, are critical to accomplishing successful work and achieving an organizational strategy'. In their model, they define the functional level, which means that competencies cascade from the core competencies and are associated with specific work functions or business units. According to the results, it would be interesting to check whether this would be confirmed by further analysis of the specific competencies of individual subjects.

\section{Conclusion}

The study results are interesting for several reasons. First of all, because a set of competencies (or knowledge, skills and desirable behaviors) was created from com- 
petencies that (1) emphatically emphasize theoretical contributions, from the results of previous projects and from 'professional' accreditation associations, (2) are listed in the study programs of renowned universities, and (3) are exposed to concrete working practice. Altogether more than 1,600 perceived competencies were detected. By analyzing the above set of competencies, a lot of substantive coherence was identified among individual competencies, therefore it was possible to perform a certain unification. The result is that 61 competencies link 'theory' and 'practice' in the area of education or functioning in administration. The list includes competencies that are summarized from those jobs that require an undergraduate or graduate study degree in the field of public administration. The study, therefore, demonstrates the development of the necessary competencies for education in the field of administrative sciences. The results show a significant match in the ranks of competencies studied and the importance of generic competencies. Along with other research, in our study, general competencies seem to be more important than specific ones.

Based on the expected 'standardization' of knowledge (competencies) that arises from the accreditation criteria and international standards (mainly from the two most important accreditation institutions for the field of public administration education, the EAPAA and NASPAA), a set of competencies is used in different environments. However, even though a set of competencies has been expanded with competencies from our preliminary study, similar research should also be carried out in other countries. On the basis of the results obtained, potential differences in employers' views could be identified (their assessment of which competence would be appropriate to develop in the public administration study programs for undergraduate and graduate students). A comparison between countries would show potential differences in desirable competencies. In this way, the adequacy of the definition of the competencies required in the study programs by (accredited) accreditation organizations could also be checked. All these would encourage an even greater need to use competence-based learning in study programs.

\section{References:}

1. American Public Health Association, 'Environmental Health Competency Project: Recommendations for Core Competencies for Local Environmental Health Practitioners', National Center for Environmental Health, Centers for Disease Control and Prevention, May 2001, [Online] available at https://www.cdc.gov/nceh/ehs/corecomp/ core_competencies_eh_practice.pdf, accessed on December 23, 2017.

2. Avargil, S., Herscovitz, O. and Dori, Y.J., 'Teaching Thinking Skills in Context-based Learning: Teachers' Challenges and Assessment Knowledge', 2012, Journal of Sciences Education and Technology, vol. 21, no. 2, pp. 207-225.

3. Awortwi, N., 'Building New Competencies for Government Administrators and Managers in an Era of Public Sector Reforms: The Case of Mozambique', 2010, International Review of Administrative Sciences, vol. 76, no. 4, pp. 723-748.

4. Azevedo, A., Apfelthaler, G. and Hurst, D., 'Competency Development in Business Graduates: An Industry-driven Approach for Examining the Alignment of Under- 
graduate Business Education with Industry Requirements', 2012, The International Journal of Management Education, vol. 10, no. 1, pp. 12-28.

5. Bonder, A., Bouchard, C.D. and Bellemare, G., 'Competency-Based Management - An Integrated Approach to Human Resource Management in the Canadian Public Sector', 2011, Public Personnel Management, vol. 40, no. 1, pp. 1-10.

6. Boni, A. and Lozano, J.F., 'The Generic Competencies: An Opportunity for Ethical Learning in the European Convergence in Higher Education', 2007, Higher Education, vol. 54, no. 6, pp. 819-831.

7. Borza, A. and Crișan, C., 'Employers' Expectations: Competencies of Entrepreneurs versus Competencies of Graduates of Higher Education', 2012, Quality Assurance Review for Higher Education, vol. 4, no. 2, pp. 29-40.

8. Brown, P. and Smetherham, C., 'The Changing Graduate Labour. Market: A Review of the Evidence', Technical Report for the Welsh Assembly, 2006, [Online] available at http://200.6.99.248/ bru487cl/files/libros/Tendencias/pdf/rr7-e.pdf, accessed on December 22, 2017.

9. Civil Services Human Resources, 'Civil Service Competency Framework 2012-2017', 2015, [Online] available at https:/www.gov.uk/government/uploads/system/uploads/ attachment_data/file/436073/cscf_fulla4potrait_2013-2017_v2d.pdf, accessed on December 23, 2017.

10. Clark, I.D. and Pal, L.A., 'Master's of Public Administration and of Public Policy: An Analysis of Academic Programs and Professional Competencies in Canada', 2011, Croatian and Comparative Public Administration, vol. 11, no. 4, pp. 947-984.

11. Clemente-Ricolfe, J.S. and Escribá-Pérez, C., 'Análisis de la Percepción de las Competencias Genéricas Adquiridas en la Universidad', 2013, Revista de Educación, no. 362, pp. 535-561.

12. European Commission, 'Survey Eurobarometer: Employers' Perception Considering Graduates Employability', 2010, [Online] available at http://ec.europa.eu/public_opinion/flash/fl_304_en.pdf, accessed on December 22, 2017.

13. European Commission, 'Tuning Educational Structure in Europe, Closing Conference', 2002, [Online] available at http://www.aic.lv/bolona/Bologna/Reports/projects/ Tuning/Tun_Book.pdf, accessed on December 22, 2017.

14. Evenson, W.E., 'Strengthening Student Learning Through 'Tuning', 2012, Journal of Science, Technology, Ethics and Policy, vol. 3, no. 1, pp. 18-24.

15. Forgues-Savage, L. and Wong, S., 'Competency Management in Canada's Core Public Administration', Office of the Chief Human Resources Officer, Treasury Board Secretariat in Canada, 2017, [Online] available at https://soc.kuleuven.be/io/onderzoek/project/files/hrm27-country-report-canada.pdf, accessed on December 20, 2017.

16. Frasquet, M., Calderon, H. and Cervera, A., 'University-Industry Collaboration from a Relationship Marketing Perspective: An Empirical Analysis in a Spanish University Higher Education', 2012, The International Journal of Higher Education and Educational Planning, vol. 64, no. 1, pp. 85-98.

17. Giddens, A., Modernity and Self-identity: The Self and Society in the Late Modern Age, London: Polity Press, 1991.

18. Gómez, M., Aranda, E. and Santos, J., 'A Competency Model for Higher Education: An Assessment based on Placements', 2017, Studies in Higher Education, vol. 42, no. 12, pp. 2195-2215. 
19. Gonzales, J. and Wagenaar, R., 'In Tuning Educational Structures in Europe: Final Report: Phase I', University of Duesto and University of Groningen, 2003, [Online] available at http://tuningacademy.org/wp-content/uploads/2014/02/TuningEUI_Final-Report_EN.pdf, accessed on December 22, 2017.

20. Gonzales, J. and Wagenaar, R., 'Tuning Educational Structures in Europe II: Universities' Contribution to the Bologna Process', University of Duesto and University of Groningen, 2005, [Online] available at http://tuningacademy.org/wp-content/uploads/2014/02/Universities-Contribution_EN.pdf, accessed on December 22, 2017.

21. ICAPA Accreditation, 'Standards of Excellence', 2008, [Online] available at www.icapa-accreditation.org/about-icapa/standards-of-excellence/, accessed on September 30, 2016.

22. IPMA-HR, 'Certification', International Personnel Management Association for Human Resources and Training Center of State Administration of Foreign Expert Affairs, 2005, [Online] available at http://www.ipmahr.org/content.cfm?pageid=35, accessed on May 29, 2005.

23. Jurše, M. and Tominc, P., 'Professional Competencies of Graduates as a Labour Market Mechanism for Aligning Business School Curriculum Reform with the Bologna Declaration Principles', 2008, Journal of Contemporary Management Issues, vol. 13, no. 1, pp. 17-36.

24. Kuijpers, M. and Meijers, F., 'Learning for Now or Later? Career Competencies among Students in Higher Vocational Education in the Netherlands', 2012, Studies in Higher Education, vol. 37, no. 4, pp. 449-467.

25. Kuijpers, M., Schyns, B. and Scheerens, J., 'Career Competencies for Career Success', 2006, Career Development Quarterly, vol. 55, pp. 168-179.

26. Kuijpers, M.A.C.T. and Scheerens, J., 'Career Competencies for the Modern Career', 2006, Journal of Career Development, vol. 32, no. 4. pp. 303-319.

27. Lee, J.M., 'Articulation of Undergraduate and Graduate Education in Public Health', 2008, Public Health Reports, vol. 123, suppl. 2, pp. 12-17.

28. Lokhoff, J., Wegewijs, B., Durkin, K., Wagenaar, R., González, J., Isaacs, A.K., Donà dalle Rose, L.F. and Gobbi, M. (eds.), 'A Tuning Guide to Formulating Degree Programme Profiles', Bilbao, Universidad del Deusto, 2010, [Online] available at http:// www.unideusto.org/tuningeu/images/stories/documents/Tuning_Guide._Degree_ programme_profiles.pdf, accessed on December 22, 2017.

29. Lowden, K., Hall, S., Elliot D. and Lewin, J., 'Employers' Perceptions of the Employability Skills of New Graduates', University of Glasgow, 2011, [Online] available at https://www.kent.ac.uk/careers/docs/Graduate_employability_skills\%202011.pdf, accessed on December 22, 2017.

30. Manly, S., McKnight, C.A. and Thomas, D.W., 'Generic and Specific Skills: Stakeholders' Perceptions and Evidence of Change', 2008, Journal of Business Administration Online, vol. 7, no. 1, [Online] available at https://www.atu.edu/jbao/spring2008/manly_ mcknight_thomas_final_version.doc, accessed on December 22, 2017.

31. Martínez, P.A.L., Moreno, J.J.M. and Brage, L.B., 'Analysis of Professional Competencies in the Spanish Public Administration Management', 2014, Journal of Work and Organizational Psychology, vol. 30, no. 2, pp. 61-66.

32. Melnikova, J., 'The Holistic Model of Capability of Lithuanian School Heads: Theoretical Framework and Empirical Evidence', 2013, Social Research, vol. 31, no. 2, pp. 13-23. 
33. NASPAA, 'Accreditation Standards for Master's Degree Programs', 2009, [Online] available at https://naspaaaccreditation.files.wordpress.com/2015/02/naspaa-accreditation-standards.pdf, accessed on December 10, 2017.

34. NASPAA, 'Accreditation Standards. Commission on Peer Review and Accreditation', 2014, [Online] available at https://naspaaaccreditation.files.wordpress.com/2015/02/ naspaa-accreditation-standards.pdf, accessed on May 13, 2016.

35. NCVER, 'Defining Generic Skills: At a Glance', Adelaide, South Australia: The National Council for Vocational Education Research, 2003, [Online] available at https://www. ncver.edu.au/_data/assets/file/0020/4457/nr2102b.pdf, accessed on May 14, 2016.

36. Oduma, C.A. and Ile, C.M., 'Leadership Competencies Desired by Employers of Business Education Graduates for Effective Job Performance in Business Organizations', 2012, African Research Review, vol. 6, no. 2, pp. 171-180.

37. Picket, L., 'Competencies and Managerial Effectiveness: Putting Competencies to Work', 1998, Public Personnel Management, vol. 27, no. 1, pp. 103-115.

38. Plewa, C. and Quester, P.G., 'Key Drivers of University-Industry Relationships: The Role of Organisational Compatibility and Personal Experience', 2007, Journal of Services Marketing, vol. 21, no. 5, pp. 370-382.

39. Profiroiu, A.G., 'Lecturer and Student Perspective regarding Teaching Public Administration in Romania', 2013, Transylvanian Review of Administrative Sciences, Special Issue, pp. 141-155.

40. Reichard, C. and van der Krogt, T., 'PA-Specific Competence Areas, Concept v2', 2014, [Online] available at https://docs.google.com/file/d/0B5JqxdPph9w_bUJrb3QxQWZTQ28/edit, accessed on October 10, 2014.

41. Rosenbaum, A., In Quest of Excellence: Approaches to Enhancing the Quality of Public Administration Education and Training, Bratislava: NISPAcee Press, 2015.

42. Savickas, M.L., 'Career Development and Public Policy: The Role of Values, Theory, and Research', in Hiebert, B. and Bezanson, L. (eds.), Making Waves: Career Development and Public Policy, Ottawa: Canadian Career Development Foundation, 2000, pp. 48-59.

43. Shevchenko, A., 'The Essence and Structure of Masters' of Public Administration Core Competencies in the USA', 2016, Comparative Professional Pedagogy, vol. 6, no. 3, pp. 62-68.

44. Tasopoulou, K. and Tsiotras, G., 'Benchmarking towards Excellence in Higher Education', 2017, Benchmarking: An International Journal, vol. 24, no. 3, pp. 617-634.

45. Tuning, 'Tuning Methodology', 2016, [Online] available at http://www.unideusto. org/tuningeu/images/stories/archivos/TUNING\%20METHODOLOGY\%20PARA\%20 LA\%20WEB.pdf, accessed on September 10, 2017.

46. United Nations Department of Economic and Social Affairs, 'Task Force on Standards of Excellence for Public Administration Education and Training', Final Report, 2008, [Online] available at http://unpan1.un.org/intradoc/groups/public/documents/undpadm/unpan034307.pdf, accessed on December 22, 2017.

47. Uredba (regulation), 'Uredba o notranji organizaciji, sistemizaciji, delovnih mestih in nazivih v organih javne uprave in v pravosodnih organih. Priloga I. Opisi tipičnih uradniških Delovnih mest' (Decree on Internal Organization, Systemization, Posts and Titles in Public Administration bodies and Judicial Bodies. Annex I. Descriptions of Typical Official Posts), 2003, Uradni list Republike Slovenije, št. 58/03. 
48. van der Krogt, T. and Reichard, C., 'Competences and Learning Outcomes: The Tuning-PA Project, Version 5’, October 2013, [Online] available at https://sites.google.com/ site/tuningpaproject/recent-uploaded-files/Downloads, accessed on December 22, 2017.

49. van Jaarsveldt, L.C. and Wessels, J.S., 'Information Technology Competence in Undergraduate Public Administration Curricula at South African Universities', 2015, International Review of Administrative Sciences, vol. 81, no. 2, pp. 412-429.

50. Varga, E., Hajós, L. and Szira, Z., 'The Examination of Relevant Competencies in the Labour Market from the Point of View of Employers', 2016, ANNALS of Faculty Engineering Hunedoara - International Journal of Engineering, vol. XIV, no. 2, pp. 155-159.

51. Vila, L.E., Perez, P.J. and Morillas, F.G., 'Higher Education and the Development of Competencies for Innovation in the Workplace', 2012, Management Decision, vol. 50, no. 9, pp. 1634-1648.

52. Winterton, J., 'Competence Across Europe: Highest Common Factor or Lowest Common Denominator?', 2009, Journal of European Industrial Training, vol. 33, no. 8/9, pp. 681-700.

53. Želvys, R. and Akzholova, A., 'Challenges of Applying Competence-Based Learning in Higher Education', 2016, Būsimuju anglu kalbos mokytoju požiūris i savarankiška darba kaip viena iš universitetiniu studiju sudedamuju daliu, Acta Paedagogica Vilnensia, vol. 36, pp. 9-33. 